\title{
Diels-Alder Synthesis of Trisbicyclo[2.2.1]heptabenzene
}

\section{Key words}

trisbicyclo[2.2.1]heptabenzene

cyclohexatriene

Diels-Alder cycloaddition

\section{SYNFACTIth}<smiles>CC(=O)OC(C)=C1C(C(C)=O)=C2CC1c1c2c2c(c3c1C1C=C(C(C)=O)C3C1C(C)=O)C1CC2C(C(C)=O)=C1C(C)=O</smiles>

trans-3 confirmed by XRD<smiles>BrC1CC(Br)c2c1c1c(c3c2C(Br)CC3Br)C(Br)CC1Br</smiles><smiles></smiles>

cis-3 not present in crystals

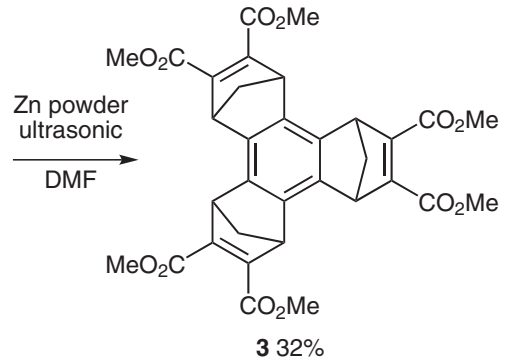<smiles>CC(=O)OC(C)=O</smiles>

not observed
Significance: The authors report the synthesis of a cyclohexatriene containing trisbicyclo[2.2.1] heptabenzene that does not involve highly reactive organometallic intermediates. The critical step involves a triple Diels-Alder cycloaddition between the tri-diene formed from 1,3,4,6,7,9-hexabromotrindane and dimethyl but-2-ynedioate. The desired product $\mathbf{3}$ was obtained in 32\% yield. The structure of trans-3 was confirmed by X-Ray crystal structural analysis.
Comment: The cyclohexatriene motif has a lot of potential for uses in materials and supramolecular chemistry. Compounds containing this subunit have been used in the synthesis of fullerene and trindane analogues. In addition, tris(bicyclo[2.1.1]hexeno) benzene was the first example of a mononuclear benzenoid compound with observable bond alternation (localization), causing its analogues to be of theoretical interest (J. S. Siegel Angew. Chem. Int. Ed. 1995, 34, 1454). This synthesis provides a less toxic and costly route to such compounds. 